\title{
TOXIC EFFECTS OF CARBON TETRACHLORIDE ON THE PRIMARY HEPATOCYTE CULTURE FROM MONGOLIAN GERBIL (Meriones unguiculatus)
}

\author{
Itaru Yamaguchi, Katsushi Kuroki, Akinori Takahashi, \\ Shigeki Tsutsui, Masayoshi Yukawa, and Kosaku Fujiwara \\ Department of Pathology II, Nihon University School of Veterinary Medicine
}

\begin{abstract}
Carbon tetrachloride $\left(\mathrm{CCl}_{4}\right)$ hepatotoxicity to the primary hepatocyte culture of Mongolian gerbils was studied. Transaminase leakage from cultured cells appeared at $3 \mathrm{~h}$-exposure to 0.5 or $1.0 \mathrm{mM}$ $\mathrm{CCl}_{4}$, remarkably increasing at $24 \mathrm{~h}$. With $0.5 \mathrm{mM} \mathrm{CCl}_{4}$, there were marked increase of lipid droplets. aggregation of swollen smooth-surfaced endoplasmic reticulums (sER), dilatation of ER lumen, metamorphosis of mitochondria, and reduction of periodic acid-Schiff (PAS) reactivity. Cholesterol clefts were produced in ER areas at $3 \mathrm{~h}$-exposure, increasing in size and number with time course. These morphological changes due to $\mathrm{CCl}_{4}$ were enhanced by previous treating of the culture with phenobarbital. (J Toxicol Pathol 4: 137 144, 1991)

Key words : Carbon tetrachloride, Hepatocyte culture, Hepatotoxicity, Mongolian gerbil
\end{abstract}

\section{Introduction}

$\mathrm{CCl}_{4}$ is known to produce necrotizing lesions in the liver of many but not all animal species ${ }^{1-6}$. Interspecies difference in its hepatotoxicity has been ascribed to difference in ability to biotransform the chemical to reactive metabolites either covalent binding with cellular constituents or promoting lipid peroxidation process at the cellu-

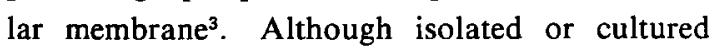
hepatocytes are being widely used for studying the mechanism of chemically induced cytotoxicity, some discrepancy has been noticed between experimental results in vitro and those in vivo ${ }^{7}$.

The Mongolian gerbil, Meriones unguiculatus, was reported to metabolize $\mathrm{CCl}_{4}$ more intensively than the rat and to show higher sensitivity to the chemical ${ }^{8,9}$. The present paper is to describe the morphological sequelae observed in cultured ger-

\section{山口 格 黒木克史 高橋章典 筒井茂樹 湯川㐤嘉}

藤原公策

Accepted for publication : June 23, 1991

Mailing address : Kosaku Fujiwara, Pathology II, Nihon University School of Veterinary Medicine, 1866 Kameino, Fujisawa, Kanagawa 252, Japan. bil hepatocytes exposed to $\mathrm{CCl}_{4}$ to have further information to the $\mathrm{CCl}_{4}$ hepatotoxicity in this species of animals showing characteristic metabolism of lipids or cholesterols $\mathrm{s}^{\mathrm{8}, 10-12}$.

\section{Materials and Methods}

\section{Animals}

Male Mongolian gerbils were bred in a conventional environment of this laboratory and fed commercial pellets (MF ; Oriental Yeast, Tokyo) and given tap water ad libitum. Animals aged 9 to 12 weeks weighing 60 to $70 \mathrm{~g}$ were used.

\section{Hepatocyte culture}

According to a two step perfusion method proposed by Berry and Friend ${ }^{13}$, the liver of pentobarbital sodium-anesthetized gerbils was perfused in situ for 7 min with a modified KrebsRinger bicarbonate buffer $(119.8 \mathrm{mM} \mathrm{NaCl}, 23.8$ $\mathrm{mM} \mathrm{NaHCO}, 0.6 \mathrm{mM} \mathrm{MgSO}, 0.6 \mathrm{mM} \mathrm{KH} \mathrm{KO}_{4}$ and $5 \mathrm{mM}$ HEPES, pH 7.4) containing $0.1 \mathrm{mM}$ EGTA (KR-buffer) previously warmed at $37^{\circ} \mathrm{C}$. The perfusate was introduced from the hepatic portal vein and drained via the inferior vena cava. The organ was then perfused for $7 \mathrm{~min}$ with the 
same buffer supplemented with collagenase (50 $\mathrm{mU} / \mathrm{ml}$ ) and $\mathrm{CaCl}_{2}$ (1.0 mM) (KR-C buffer). After perfusion, the liver was minced and tissues were dispersed in KR-C buffer. After gentle stirring, the suspension was filtered through a stainless mesh, and the filtrate was centrifuged at $40 \times g$ for $90 \mathrm{sec}$. The sediment was resuspended in William's medium $\mathbf{E}$ (WME) and washed three times with WME by centrifuge. The final sediment was suspended in WME supplemented with swine serum (10\%), insulin $(5 \mu \mathrm{g} / \mathrm{ml})$, dexamethasone $(4 \mathrm{ng} / \mathrm{ml})$, and kanamycin $(50 \mu \mathrm{g} / \mathrm{ml})$. The cell preparation showed a viability of $85 \%$ or higher in trypan blue exclusion test. It was introduced at a density of $7.5 \times 10^{5}$ cells / plate into $35 \mathrm{~mm}$-plastic culture dishes, which contained a collagen coated cover slip. After incubation at $37^{\circ} \mathrm{C}$ for $3 \mathrm{~h}$ in a humidified environment at $5 \%$ $\mathrm{CO}_{2}-95 \%$ air, the cultures were rinsed with warmed complete WME to remove free cells and debris. Then $2 \mathrm{ml}$ of the same medium were added to the cultures, which were incubated at $37^{\circ} \mathrm{C}$.

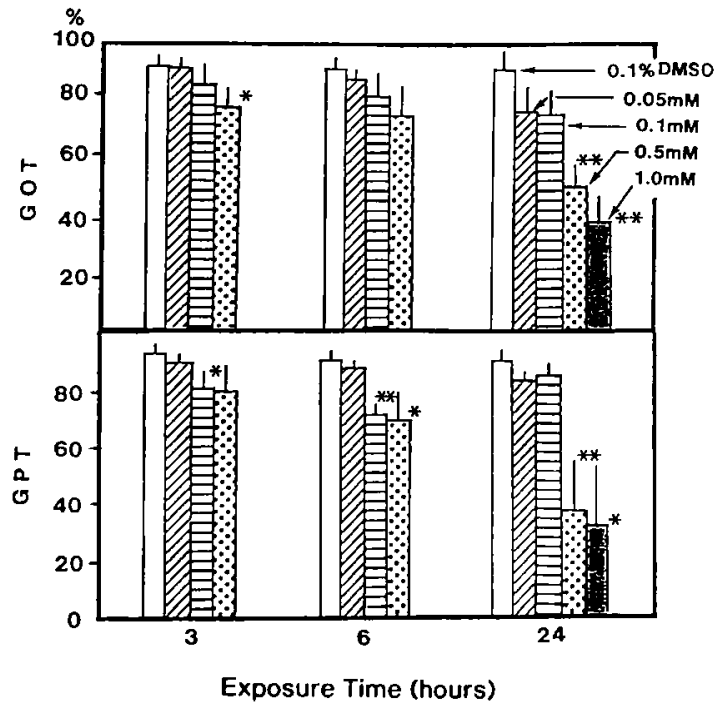

Fig. 1. Enzyme leakage from cultured gerbil hepatocytes treated with $\mathrm{CCl}_{4}$. Indicated amounts of $\mathrm{CCl}_{4}$ in DMSO were added to one day-cultures with $2 \mathrm{ml}$ medium in $35 \mathrm{~mm}$ dishes. Each bar represents a ration of enzyme activity : $[($ Cell : Cell + Medium) $\times 100$ (\%) $]$. Mean + SD from 3 animals. ${ }^{*} P<0.05,{ }^{* *} \mathbf{P}<$ 0.01 as compared with non-treated control (Student's $t$-test).

\section{Exposure to $\mathrm{CCl}_{4}$}

$\mathrm{CCl}_{4}$ (Wako Pure Chemical Industries, Osaka) was dissolved in dimethyl sulfoxide (DMSO) at a concentration of $1 \mathrm{M}$. The solution was diluted serially with serum-free complete WME, and $2 \mathrm{ml}$ of each dilution was added to $24 \mathrm{~h}$-culture of hepatocytes which were previously rinsed with warmed serum-free medium. In another experiment, cell cultures were pretreated with $2.5 \mathrm{mM}$ phenobarbital sodium (PB) (Wako Pure Chemical Industries, Osaka) for $6 \mathrm{~h}$, rinsed with the medium, and then exposed to $0.5 \mathrm{mM} \mathrm{CCl}_{4}$ for $3 \mathrm{~h}$.

4. Assays for glutamic-oxaloaceteic transaminase (GOT) and glutamic-pyruvic transaminase (GPT)

At 3, 6, and $24 \mathrm{~h}$-exposure to $\mathrm{CCl}_{4}$, the incubation medium was removed, and the cells were scraped into $2 \mathrm{ml}$ phosphate buffer $(100 \mathrm{mM}, \mathrm{pH}$ 7.2) containing $0.1 \%$ Triton $X-100$ using a teflon policeman and homogenized. The suspension was centrifuged at $10,000 \times \mathrm{g}$ for $20 \mathrm{~min}$. The supernatant and incubation medium were stocked at $-20^{\circ} \mathrm{C}$, and they were assayed for GOT and GPT activity according to Reitmann-Frankel method $^{14}$.

\section{Cytopathology}

After exposing to $\mathrm{CCl}_{4}$, hepatocyte cultures on collagen coated cover slips were observed by phase-contrast microscopy (PCM). Then cultures were fixed in formalin and stained with periodic acid-Schiff (PAS), Sudan black B(SBB), and oil red $O(O R O)$ for light microscopy, For electron microscopy some cultures were washed with WME and fixed in $2.5 \%$ glutarardehyde in $100 \mathrm{mM}$ phosphate buffer, pH 7.2 and postfixed in $1 \%$ osmium tetraoxide in the same buffer. They were dehydrated by a graded ethanol series and embedded in Epon 812 resin. Ultrathin sections were made in parallel to the culture surface and stained with uranyl acetate and lead citrate. Observation was made using a JEM-1200EX electron microscope (EM).

\section{Results}

At $3 \mathrm{~h}$-exposure to $0.5 \mathrm{mM}$ or $1.0 \mathrm{mM} \mathrm{CCl}_{4}$, the 


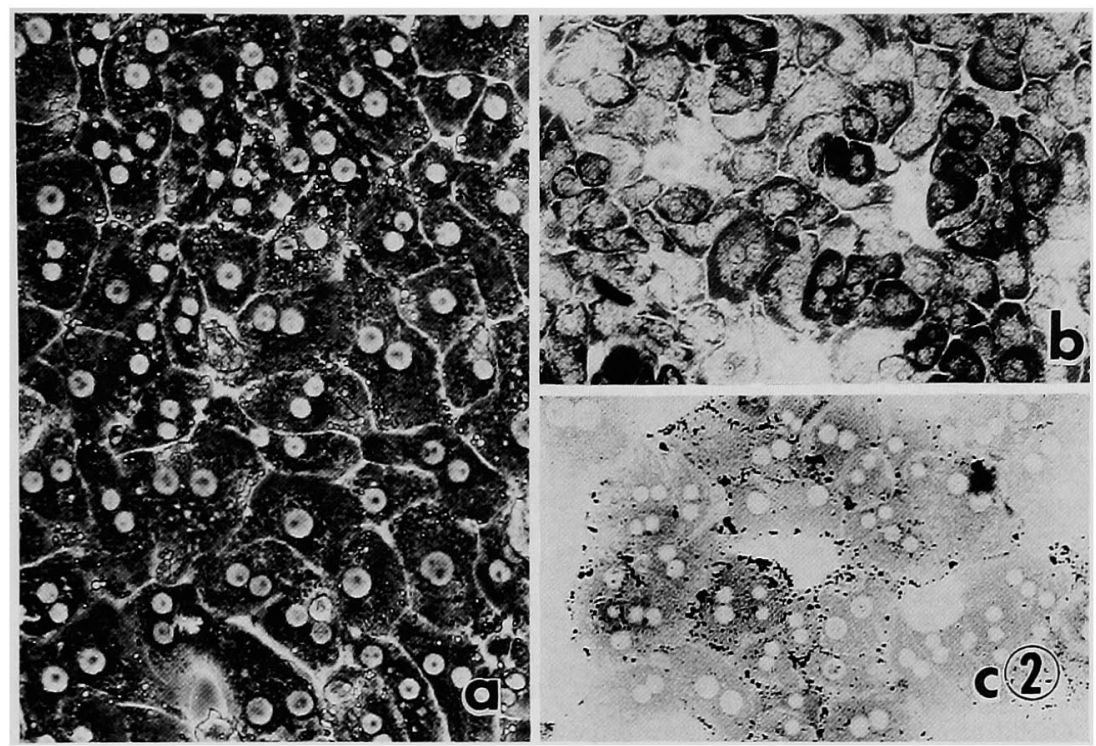

Fig. 2. Untreated gerbil hepatocyte culture at $24 \mathrm{~h}$ of incubation, stained with a) PCM, b) SBB, and c) PAS.

GOT and GPT levels of the culture medium were significantly higher as compared with those of controls (Fig. 1). The enzyme leakage was much more remarkable at $24 \mathrm{~h}$-exposure. Even with 0.1 $\mathrm{mM} \mathrm{CCl}{ }_{4}$ exposure some leakage was seen.

Untreated cultures showed a nearly confluent monolayer of polygonal hepatocytes and three to six negihbouring cells contacted each other by PCM (Fig. 2a). Each cell had one or two nuclei and clear cytoplasm with a PAS-positive marginal zone and some SBB-or ORO-positive lipid droplets (Figs. 2b and 2c). At 24 h-culture with or without $0.1 \%$ DMSO, lipid droplets were either decreased in number or disappeared, while PAS positivity still remained.

At $3 \mathrm{~h}$-exposure to $0.5 \mathrm{mM} \mathrm{CCl}_{4}$, cytoplasmic lipid droplets were increased in number, and the cytoplasm of some cells was diffusely PAS-positive at various degrees. EM revealed lucid cholesterol clefts appearing in the lumen of aggregated smoothsurfaced endoplasmic reticulum (sER) (Fig. 3).

At $6 \mathrm{~h}$-exposure, lipid droplets were numerous and diffusely distributed in the irregular-shaped cyoplasm (Figs. 4a and 4b). A number of cells were PAS negative (Fig. 4c). EM revealed an increased number of enlarged cholesterol clefts and various sized lipid droplets in aggregated sER and Golgi complex (Fig. 5). A few cells showed de-

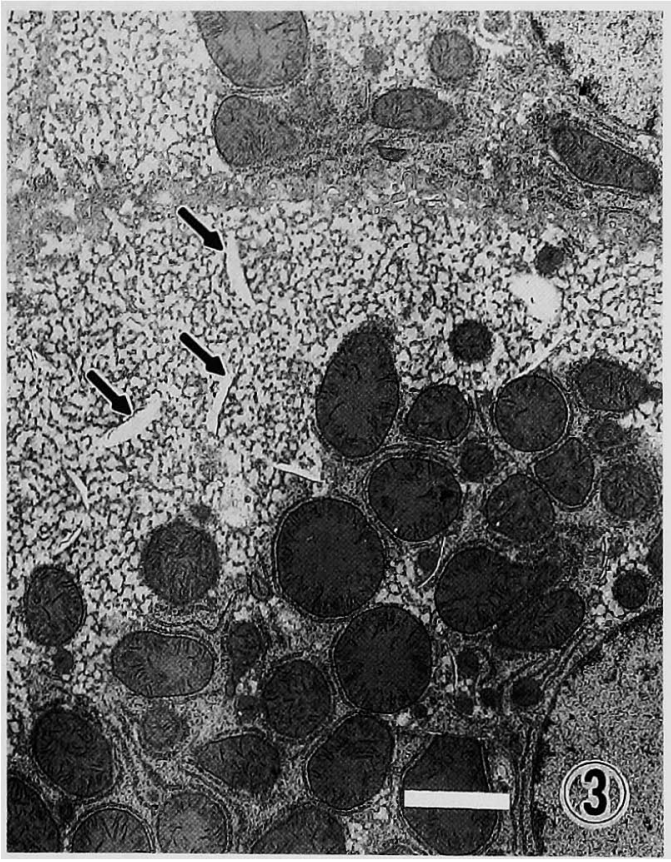

Fig. 3. Gerbil hepatocyte culture at $3 \mathrm{~h}$-exposure to $0.5 \mathrm{mM}$ of $\mathrm{CCl}_{4}$, showing some cholesterol clefts (arrows) in sER area. TEM. Bar $=2 \mu \mathrm{m}$.

granulation of rough-surfaced endoplasmic reticulum (rER) with dilated lumens, where myelin body structures were present (Fig. 6a). Aggregated choresterol clefts were surrounded by peroxisomes (Fig. 6b). There were swollen and 


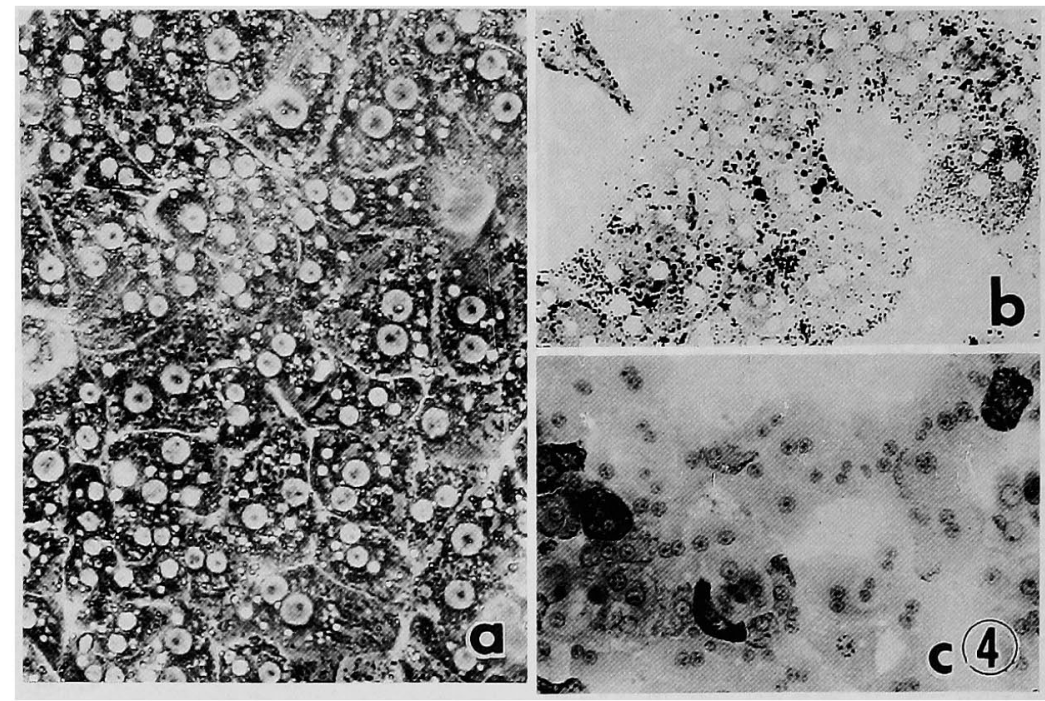

Fig. 4. Gerbil hepatocyte culture at $6 \mathrm{~h}$-exposure to $0.5 \mathrm{mM}$ of $\mathrm{CCl}_{4}$, showing lipid droplets (a, b) and reduced PAS positivity (c) in the cytoplasm. a) PCM, b) SBB, c) PAS.

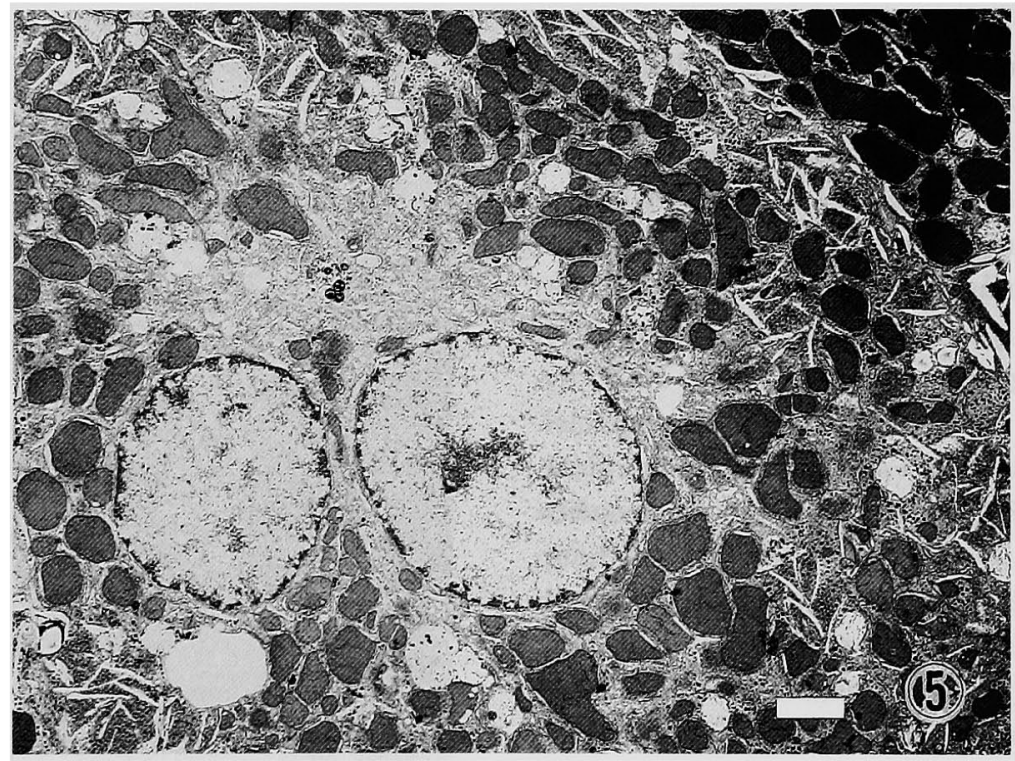

Fig. 5. Gerbil hepatocyte culture at $6 \mathrm{~h}$-exposure to $0.5 \mathrm{mM}$ of $\mathrm{CCl}_{4}$, showing an increased number of cholesterol clefts and lipid droplets. TEM. Bar $=2 \mu \mathrm{m}$.

metamorphosed mitochondria with poor cristae (Fig. 6c). Glycogen granules were reduced in number as compared with non-treated control cultures.

At 24 h-exposure to $0.5 \mathrm{mM} \mathrm{CCl}_{4}$, certain cells were necrotized being detached from the plate. PCM revealed that most cells had a great number of larger lipid droplets (Figs. 7a and 7b) showing considerably metamorphosed organelle. Most cells were PAS-negative and a few cells showed a dark cytoplasm. By EM a number of lipid droplets were shown to be deformed, and degranulated rER were disorganized with dilated lumen. A few cells were shown to have aggregated sER or rER, irregular-shaped mitochondria, and remarkably larger cholesterol clefts (Fig. 8).

After exposure to $0.1 \mathrm{mM} \mathrm{CCl}_{4}$ for $6 \mathrm{~h}$, lipid droplets were slightly increased in number, and 

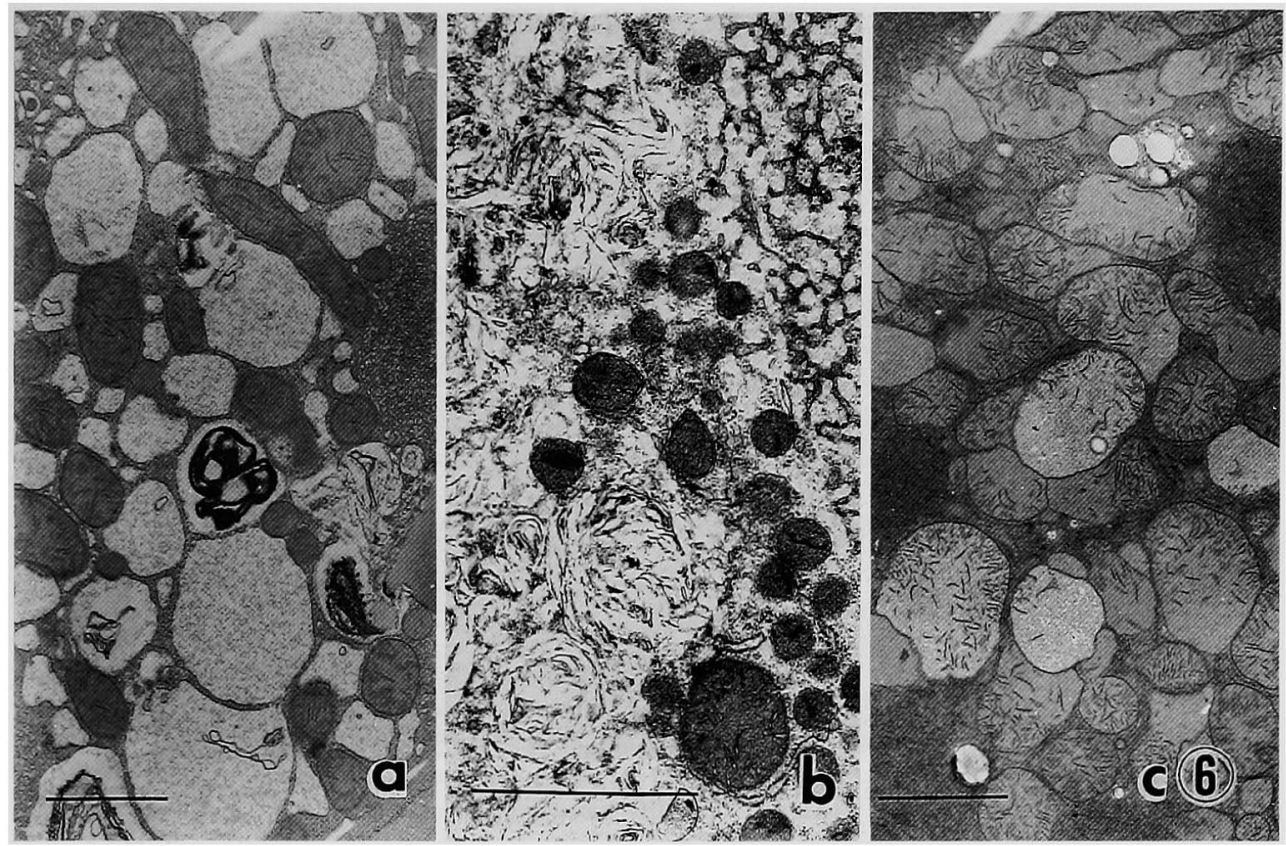

Fig. 6. Gerbil hepatocyte culture at $6 \mathrm{~h}$-exposure to $0.5 \mathrm{mM}$ of $\mathrm{CCl}_{4}$, showing dilated ER lumen (a), aggregated cholesterol clefts surrounded by peroxisomes (b), and swollen mitochondria (c). TEM. $\mathrm{Bar}=2 \mu \mathrm{m}$.

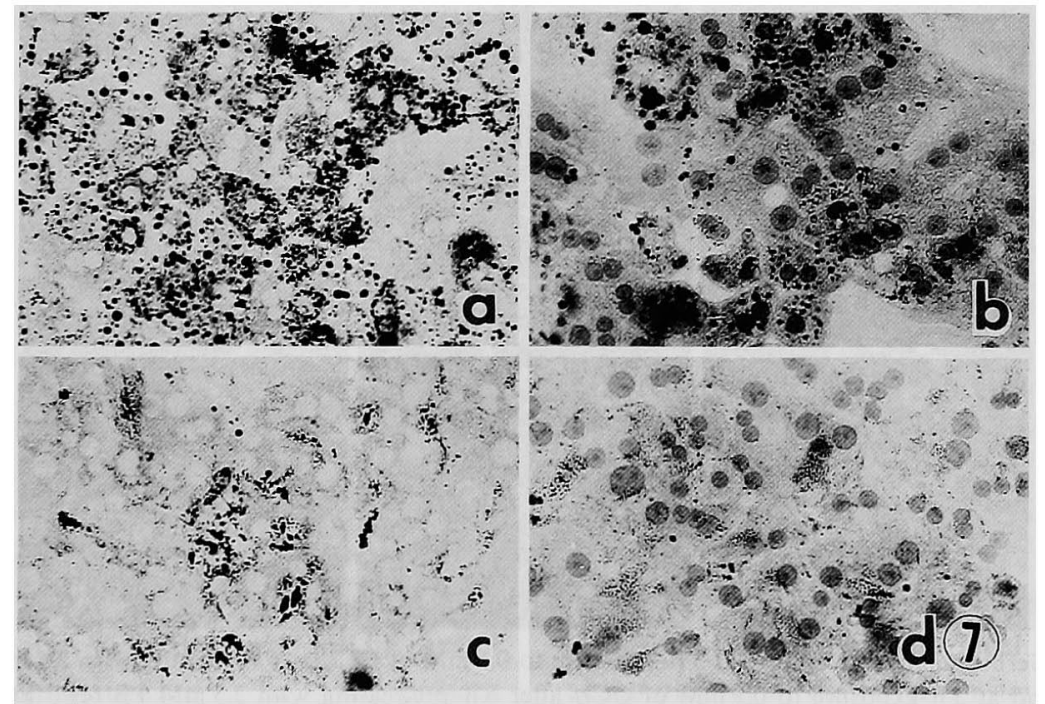

Fig. 7. Gerbil hepatocyte culture at $24 \mathrm{~h}$-exposure to $0.5 \mathrm{mM}(\mathrm{a}, \mathrm{b})$ or $0.1 \mathrm{mM}(\mathrm{c}, \mathrm{d})$ of $\mathrm{CCl}_{4}$. $\mathrm{SBB}(\mathrm{a}$, c) or ORO (b, d) stain.

small cholesterol clefts appeared within the lumen of sER. At $24 \mathrm{~h}$-exposure a few cells had enlarged lipid droplets being diffusely positive for SBB and ORO (Figs. 7c and 7d). The number of PASpositive cells were smaller as compared with untreated control cultures.
After treating with $2.5 \mathrm{mM}$ PB for $6 \mathrm{~h}$, cultured hepatocytes seemed to be metabolically activated showing abundant ER areas (Fig. 9a). The subsequent exposure to $0.5 \mathrm{mM} \mathrm{CCl}_{4}$ for $3 \mathrm{~h}$, the number of cytoplasmic droplets and vacuoles were increased more remarkably than in case of non-PB 


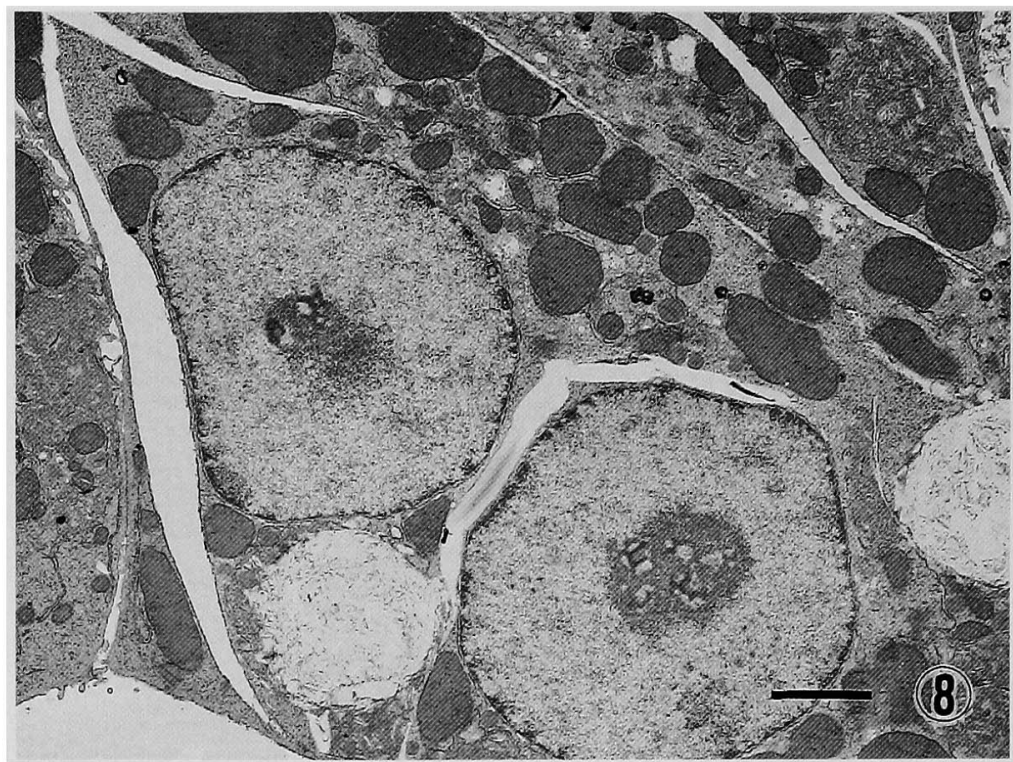

Fig. 8. Gerbil hepatocyte culture at $24 \mathrm{~h}$-exposure to $0.5 \mathrm{mR}$ of $\mathrm{CCl}_{4}$, showing numerous large cholesterol clefts. TEM. Bar $=2 \mu \mathrm{m}$.
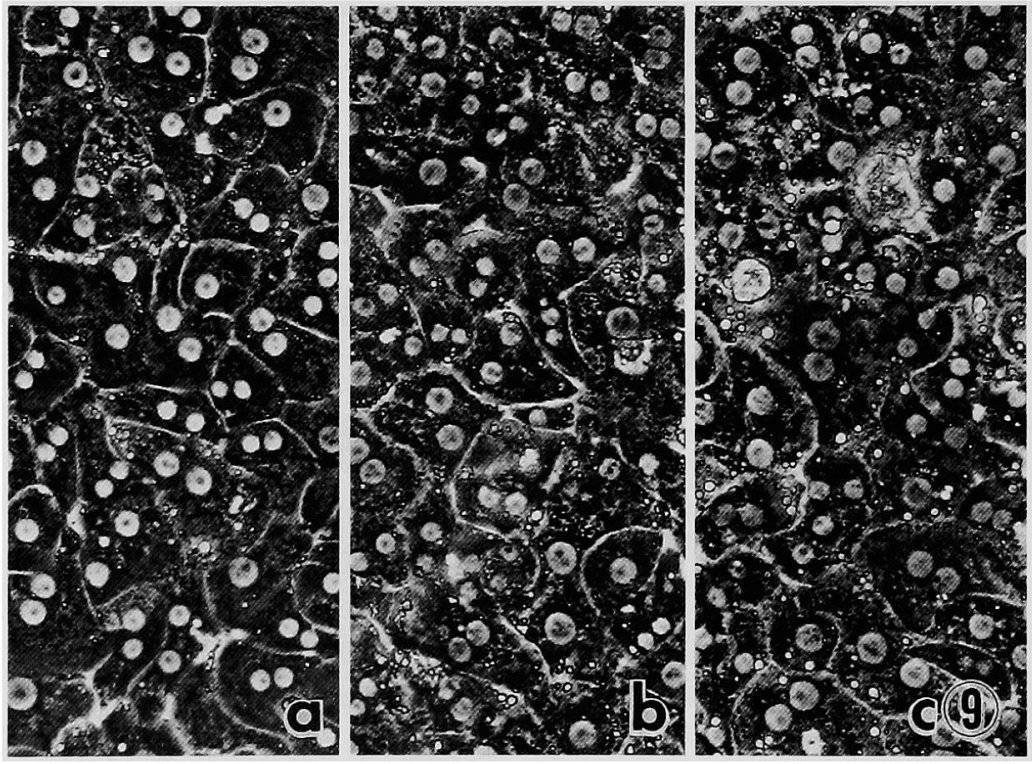

Fig. 9. Gerbil hepatocyte culture at $3 \mathrm{~h}$-exposure to $0.5 \mathrm{mM}$ of $\mathrm{CCl}_{4}$ at $6 \mathrm{~h}$-treating with $2.5 \mathrm{mM} \mathrm{PB} \mathrm{(a,}$ b), and at $3 \mathrm{~h}$-exposure to $0.5 \mathrm{mM}$ of $\mathrm{CCl}_{4}$ after $6 \mathrm{~h}$-pretreating with $2.5 \mathrm{mM} \mathrm{PB}$ (c). PCM.

treated control cultures (Figs. 9b and 9c). The lumens of ER, Golgi complex, and nuclear membrane were considerably distended and a number of larger cholesterol clefts were produced within aggregated $\mathrm{sER}$ in $\mathrm{PB}$-treated and $\mathrm{CCl}_{4}$-exposed cultures (Fig. 10).

\section{Discussion}

The primary culture of rat or mouse hepatocytes has been reported to be a useful model for $\mathrm{CCl}_{4}$ hepatotoxicity ${ }^{15-18}$. Nakamura et $a l^{15}$. reported LDH and GOT leakage and morphologic changes in the primary rat hepatocyte cultures after expo- 


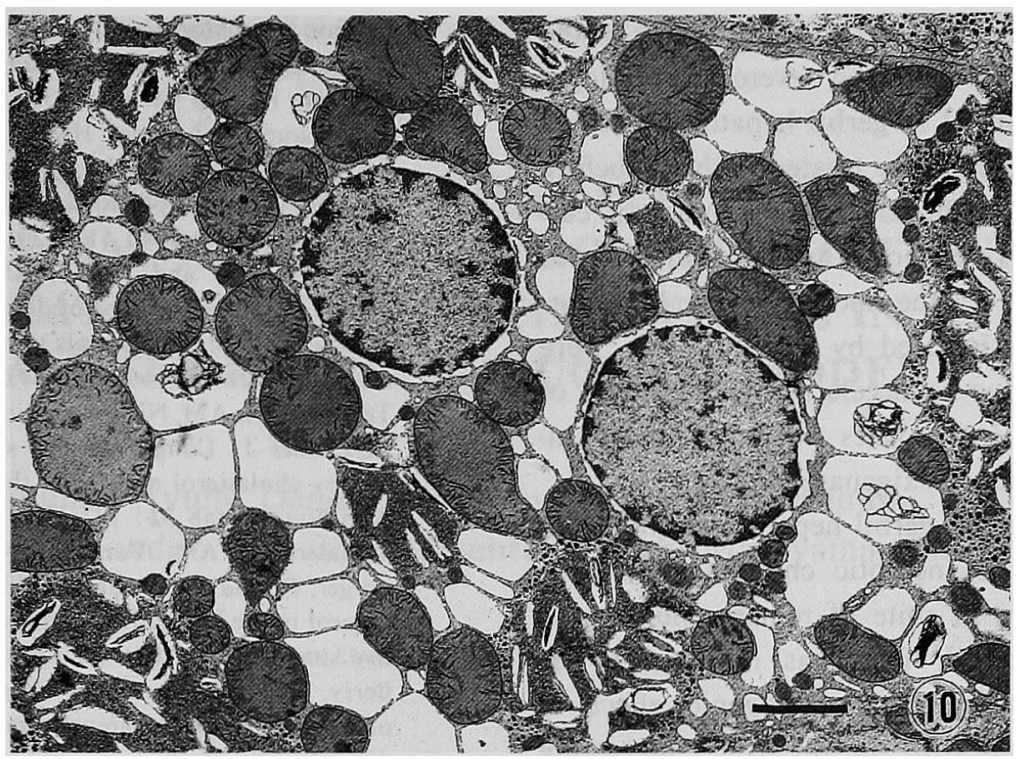

Fig. 10. Gerbil hepatocyte culture at $3 \mathrm{~h}$-exposure to $0.5 \mathrm{mM}$ of $\mathrm{CCl}_{4}$ after $6 \mathrm{~h}$-pretreating with $2.5 \mathrm{mM}$ PB, showing dilated EM lumen, aggregated sER and remarkable production of cholesterol clefts. TEM. Bar $=2 \mu \mathrm{m}$.

sure to more than $5 \mathrm{mM}$ of $\mathrm{CCl}_{4}$. In this study, cultured hepatocytes from gerbils, which were known to be susceptible to $\mathrm{CCl}_{4}$, were shown to be very sensitive to the chemical. The leakage of GOT and GPT as well as cytopathic changes were observed already after $3 \mathrm{~h}$-exposure to $0.5 \mathrm{mM}$ of $\mathrm{CCl}_{4}$. Exposure to $0.1 \mathrm{mM}$ of $\mathrm{CCl}_{4}$ also induced a mild enzyme leakage and some lipid accumulation at $24 \mathrm{~h}$. These findings agreed with liver cell injury induced in vivo in the gerbil treated with $\mathrm{CCl}_{4}$.

The fat accumulation in the liver occurring shortly after $\mathrm{CCl}_{4}$ treating, might result from blocking of lipoprotein secretion in consequence of convalent bindngs of $\mathrm{CCl}_{4}$ metablolites with the cell structure ${ }^{16,19,20}$. However, it was reported that no severe fatty liver was produced in the gerbil after $\mathbf{C C l}_{4}$ administration. In the present cytopathic study, the cultured gerbil hepatocytes were shown to have remarkable lipid deposits being ORO and SBB-positive after $\mathrm{CCl}_{4}$ exposure. In gerbils naturally living in dry environment, lipid catabolism might be of importance for energy production, and this species of animals normally has a higher lipid content in the liver than the rat ${ }^{8}$. The lipid droplets in gerbil hepatocytes were reduced in culture without reduction of glycogen.
The lipid accumulation in cultured gerbil hepatocytes exposed to $\mathrm{CCl}_{4}$, seemed to result from blocking of lipid metabolism, lipoprotein secretion, or lipid catabolism.

In the present study, characteristic cholesterol clefts appeared in ER areas of cultured gerbil hepatocytes at a very early stage of exposure to 0.1 or $0.5 \mathrm{mM} \mathrm{CCl}_{4}$. The clefts increased in size and number with time course at higher concentration of $\mathrm{CCl}_{4}$, suggesting that $\mathrm{CCl}_{4}$ inhibited cholesterol metabolism. The hepatocyte secretion of very low density lipoprotein (VLDL) ${ }^{13,14}$ integrating cholesterol might be inhibited by $\mathrm{CCl}_{4}$, while no cholesterol clefts have been described in the rat hepatocytes exposed to $\mathrm{CCl}_{4}$. The gerbil is known to respond promptly to dietary cholesterol showing a marked rise of its serum level and considerable accumulation of cholesterol ester in the liver ${ }^{10-12}$. These findings might be due to a low grade turnover of cholesterol including its catabolism in the gerbil liver. The appearance of intracellular clefts of cholesterol ester in $\mathrm{CCl}_{4}$-treated gerbil hepatocyte culture might result from the inhibition of cholesterol catabolism.

Cai and Mehendale ${ }^{9}$ reported that neither chlordecone, phenobarbital nor mirex affected hepatotoxic and lethal effects of $\mathrm{CCl}_{4}$ in the gerbil 
while rather enhancing $\mathrm{CCl}_{4}$ hepatotoxicity in the rat. In this study, acute and severe morphologic changes were induced in gerbil hepatocytes, when the culture was previously treated with PB before $\mathrm{CCl}_{4}$. As the cytochrome P-450 content of cultured hepatocytes is known to be reduced with incubation time ${ }^{21,22}$, the more remarkable morphologic changes induced by $\mathrm{PB}$ plus $\mathrm{CCl}_{4}$ were assumed to be due to accelerated production of bioactive $\mathrm{CCl}_{4}$ metabolites resulting from increased level of monooxigenase.

On the other hand, gerbil hepatocytes showed a very low degree of necrotic changes after $24 \mathrm{~h}$ exposure to $\mathrm{CCl}_{4}$ in spite of remarkable enzyme leakage. The gerbil liver was reported to be comparatively resistant to necrogenic effect of $\mathrm{CCl}_{4}$ as compared with the rat liver ${ }^{8}$, suggesting that the homeostasis of hepatic calcium is more stable in the gerbil.

The cultured gerbil hepatocytes might provide a good tool for studying the mechanisms of $\mathrm{CCl}_{4}$ hepatotoxicity.

\section{References}

1. Stater, TF : Necrogenic action of carbon tetrachloride in the rat: A speculative mechanism based in activation. Nature 209: 36-40, 1966.

2. Recknagel, $\mathbf{R}$ : Carbon tetrachloride hepatotoxicity, Pharmacol Rev 19: 145-208, 1967.

3. Diaz Gometz, MI, de Castro, CR, D'Acosta, N., de Fenos, OM, de Ferreyra, EC, and Castro, JA: Species differences in carbon tetracholoride-induced hepatotoxicity: The role of $\mathrm{CCl}_{4}$ activation and of lipid peroxidation. Toxcol Appl Pharmacol 34: 102-114, 1975.

4. Bernacchi, AS, de Castro, CR, de Ferreyra, EC, Villarruel, MC, Fernandez, G., de Fenos, OM., and Castro, JA : Carbon tetracloride induced liver injury in rabbit. Br J Exp Pathol 64 : 261-267, 1983.

5. Fernandez, G, Villarruel, MC. de Ferreyra, EC, de Fenos, OM, Bernacchi, AS, de Castro, CR, and Castro, JA: Carbon tetrachloride induced early biochemical alterations but not necrosis in pigeons liver. Agents Actions 15 : 463-466, 1984.

6. Bernacchi, AS, de Castro, CR, de Toranzo, EGD, de Ferreyra, EC, de Fenos, OM, and Castro, JA : Effects of carbon terachloride on the liver of chickens: Early biochemical and ultrastructural alternation in the absence of detectable lipid peroxiclation. Xenobiotica 17: 223-228, 1987.

7. Klaasen, CD and Stacey, NH : In Toxicology of the Liver, Raven Press, New York, pp. 117-179, 1982.

8. de Perez, OA, de Ferreyra, EC, Bernacchi, AS, Villarruel, MC, de Fenos, OM, and Castro, JA :
Carbon tetrachloride-induced liver cell injury in the Mongolian gerbil (Meriones unguiculatus). Comp Biochem Physiol 94e : 357-364, 1989.

9. Cai, $\mathrm{Z}$ and Mechendale, $\mathrm{HM}$ : Lethal effect of $\mathrm{CCl}_{4}$ and its metabolism by Mongolian gerbils pretreated with chlordecone, phenobarbital or mirex. Toxcol Appl Pharmacol 104: 511-520, 1990.

10. Anderson, DB and Holub, BJ : Effect of dietary cholesterol level and type of dietary carbohydrate on hepatic and plasma sterols in the gerbil. Can J Physiol Pharmacol 60: 885-892, 1982.

11. Temmerman, AM, Niezen-Koning, K. Berger, R, and Fernandes $\mathbf{J}$ : Long-term and short-term effects of dietary cholesterol and fat in the Mongolian gerbil. Ann Nutr Metab 32 : 177-185, 1988.

12. Temmerman, AM, Vonk, RJ, Niezen-Koning, $K$, Berger, $\mathbf{R}$, and Fernandes $\mathbf{J}$ : Effects of dietary cholesterol in the Mongolian gerbil and rat : a comparative study. Lab Anim 23 : 30-35, 1989.

13. Berry, MN and Friend, DS : High yield preparation of isolated rat liver parenchymal cells. J Cell Biol 43 : 506-520, 1969.

14. Reitman, S and Frankel, S: A colorimetric method of the determination of serum oxaloacetic and glutamic pyruvic transaminases. Am J Clin Pathol 28 : 53-56, 1957.

15. Nakamura, T, Fujii, T, and Ichihara, A : Enzyme leakage due to change of membrane permeability of primary cultured rat hepatocytes treated with various hepatotoxins and its prevention by glycyrrhizin. Cell Biol Toxicol 1 : 285-295, 1985.

16. Ruch, RJ, Klaunig, JE, Schulty, NE, Askari, AB, Lacher, DA, Pereira, MA, and Goldblatt, PJ : Mechanisms of chloroform and carbon tetrachloride toxicity in primary cultured mouse hepatocytes. Environ Health Perspect 69 : 301-305, 1986.

17. Becker, E, Messner, B, and Berndt, J : Two mechanisms of $\mathrm{CCl}_{4}$-induced fatty liver: Lipid peroxidation or covalent bindings studied in cultured rat hepatocyte. Free Radic Ret Commun 3 : 299-308, 1987.

18. Long, RM and Moore, L: Biochemical evaluation of rat hepatocyte primary cultured as a model for carbon tetracloride hepatotoxicity: Comparative studies in vivo and in vitro. Toxicol Appl Pharmacol 92 : 295-306, 1988.

19. Slater, TF : Hepatotoxicity of carbon tetrachloride : Fatty degeneration. In : Free Radical Mechanisms in Tissue Injury, J.R. Lagnago, ed., Pion Ltd, London, 1972.

20. Brittin, WJ, Glende, EA, Jr, and Recknegal, RO : Pathological mechanisms in carbon tertrachloride hepatotoxicity. J Free Rad Biol Med 1 : 27-38, 1985.

21. Bissell, DM and Guzelian, PS : Phenotypic stability of adult rat hepatocytes in primary monolayer culture. Ann NY Acad Sci 349: 85-98, 1980.

22. Steward, AR, Dannan, GA, Guzelian, PS, and Guengerich FP: Changes in the concentration of seven forms of cytochrome P-450 in primary cultures of adult rat hepatocytes. Mol Pharmacol 27 ; 125 132, 1985. 